Institute for Research on Poverty

Discussion Paper no. 1152-97

\title{
Are Public Housing Projects Good For Kids?
}

\author{
Janet Currie \\ Department of Economics \\ UCLA and NBER \\ E-mail: currie@simba.sscnet.ucla.edu \\ Aaron Yelowitz \\ Department of Economics \\ UCLA and NBER \\ E-mail: yelowitz@prometheus.sscnet.ucla.edu
}

December 1997

We thank Joshua Angrist, Caroline Minter Hoxby, Lawrence Katz, Jeffrey Kling, Edgar Olsen, Steve Pishke, James Poterba, and seminar participants at Harvard, MIT, and the NBER Summer Institute for helpful comments. Currie thanks NICHD for support under grant \#1R01 HD 31722. The computer programs and data used in this study may be obtained from the authors.

IRP publications (discussion papers, special reports, and the newsletter Focus) are now available on the Internet. The IRP Web site can be accessed at the following address: http://www.ssc.wisc.edu/irp/ 


\begin{abstract}
One goal of federal housing policy is to improve the prospects of children in poor families. But little research has been conducted into the effects on children of participation in housing programs, perhaps because it is difficult to find data sets with information about both participation and interesting outcome measures. This paper combines data from several sources to provide a first look at the effects of participation in public housing projects on housing quality and on the educational attainment of children.

We first use administrative data from the Department of Housing and Urban Development to impute the probability that a Census household lives in a public housing project. We find that a higher probability of living in a project is associated with poorer outcomes. We then use a two-sample instrumental variables (TSIV) technique to combine information on the probability of living in a project, obtained from the 1990 to 1995 Current Population Surveys, with information on outcomes obtained from the 1990 Census. The instrument common to both samples is an indicator equal to one if the household is entitled to a larger housing project unit because of the sex composition of the children in the household. Families entitled to a larger unit because of sex composition are 24 percent more likely to live in projects. When we control for omitted variables bias using TSIV, we find that project households are less likely to suffer from overcrowding and less likely to live in high-density complexes. Project children are also 12 to 17 percentage points less likely to have been held back in school one or more grades, although this effect is confined to boys. Thus, most families do not face a tradeoff between housing quality and child outcomes—-the average project improves both.
\end{abstract}




\section{Are Public Housing Projects Good For Kids?}

Since 1937, the federal government has subsidized the housing costs of some low-income families, with the stated goal of improving the quality of housing inhabited by the poor. Given that poor families with children make up 60 percent of the public housing caseload (most of the rest are households headed by the elderly and/or disabled), it is clear that a second important goal is to improve the life-chances of recipient children.

The real costs of this assistance (in 1996 dollars) have grown steadily over time, from $\$ 7.3$ billion in 1977 to $\$ 26$ billion in 1996. The number of households assisted has also risen from approximately 3.2 million in 1977 to 5.7 million in 1996, and outlays per unit have approximately doubled over the same period to $\$ 5,480$ (Committee on Ways and Means, 1996). However, public dissatisfaction with large public housing projects has remained high. Twenty-five years ago, Henry Aaron wrote that "Over the years public housing has acquired a vile image—highrise concrete monoliths in great impersonal cities, cut off from surrounding neighborhoods by grass or cement deserts best avoided after dark .... This image suggests that any benefits inhabitants derive from physical housing amenities are offset by the squalid surroundings" (Aaron, 1972: 108). Many would argue that if anything, the situation has worsened, as horrifying stories about large projects such as the Robert Taylor Homes or Cabrini Green in Chicago routinely appear in the national news.

As a result, the character of low-income housing aid has changed dramatically over time ${ }^{1}$, as money has been diverted from "project-based" aid toward "household-based" aid given in the form of

\footnotetext{
${ }^{1}$ There are other reasons for the shift in the composition of public housing from projects to vouchers. Apgar (1990) and Olsen (1983) point out that it is typically cheaper to house a family in existing housing than to construct new housing, so that more families can be served for the same budget outlay. Olsen (1983) and Olsen and Barton (1983) also argue that in addition to being more efficient, an entitlement program of housing allowances would be more equitable than the current system in which some households receive benefits and other similar households do not. Finally, programs using existing housing do not crowd out private construction of low-rent housing as public construction projects might (Murray, 1983).
} 
certificates and vouchers that can be applied toward rent in the existing private housing market. ${ }^{2}$

Moreover, since 1982, appropriations for new construction of public housing projects have fallen sharply (Committee on Ways and Means, 1996). ${ }^{3}$ And in 1995, the U. S. Department of Housing and Urban Development (HUD) put forth a plan that would have eventually replaced all "project-based" assistance with housing certificates provided directly to individual households (General Accounting Office, 1995). ${ }^{4}$

The aim of voucher/certificate programs is to assist families without consigning them to the projects. But newspaper accounts notwithstanding, there is little evidence that projects actually harm children. Basic economics suggests that families would not move into public housing unless it were better in at least some respects than the alternatives. Aaron's intriguing hypothesis is that families in projects trade off physical housing amenities and reductions in rental payments against neighborhood characteristics that are bad for their children. But many projects and project neighborhoods may actually be superior to the housing and neighborhoods that families would have occupied without assistance. And reductions in rental payments may or may not be spent on goods and services beneficial to children. Thus, it is important to look directly at the effects of housing assistance on housing quality and on child well-being.

This paper combines HUD administrative data about the demographic characteristics of households in projects with information about participation in projects from the 1990 to 1995 March Current Population Surveys (CPS) and data about outcomes from the 1990 U.S. Census to examine the effects of project participation on housing quality and on the educational attainment of children. 1996.

${ }^{2}$ In 1977, only 8 percent of assisted renters received vouchers or certificates compared with 28 percent in

${ }^{3}$ Note that even though Congress essentially stopped funding new construction of large public housing projects in the early 1980s, many families continue to live in existing projects. Thus, long lags can occur between changes in public housing policy and actual changes in the composition of the caseload.

${ }^{4}$ Specifically, instead of giving money to local housing authorities, HUD would issue certificates to all current public housing project residents. These residents would then be able to choose to stay in their current units or move elsewhere. 
We first use the HUD data to calculate the probability that each Census household lives in a public housing project. We find that a higher probability of living in a project is associated with poorer outcomes, a finding that provides a baseline for our subsequent analyses. We then use the two-sample instrumental variables (TSIV) technique developed by Angrist and Krueger $(1992,1995)$ to combine information from the CPS on the probability of living in a project with information on outcomes obtained from the Census. The instrument common to both samples is an indicator equal to one if the household is entitled to a larger housing unit in a project because of the sex composition of the children in the household. Families entitled to a larger unit based on the sex composition are 24 percent more likely to live in projects. Using TSIV to control for unobserved characteristics of project residents, we find that project families are less likely to suffer from overcrowding and more likely to live in buildings with fewer than 50 units. And children in these families are 12 to 17 percentage points less likely to have been held back in school one or more grades. Thus, families do not appear to face a tradeoff between housing quality and child outcomes-projects improve both.

Part I of the paper gives additional background information about the public housing programs. Part II discusses methods and Part III describes the data. Results appear in Part IV, and a discussion and conclusions follow in Part V.

\section{BACKGROUND}

As noted above, public housing projects tend to have very bad reputations. Yet, the publicity generated by the worst projects obscures the great heterogeneity among projects. Approximately 3,300 public housing authorities own and operate about 13,200 developments with a total of about 1.4 million units. Seventy percent of these authorities operate fewer than 300 units, while the 40 largest agencies operate 1,786 or more units and account for 36 percent of all public housing project units. HUD 
considers most of the authorities to be well run—only 3 percent are classified as "troubled" (General Accounting Office, 1995), but the eight worst large agencies account for 12 percent of all project units.

Thus it is not at all clear a priori that participation in the average project entails sacrificing either housing or neighborhood quality. ${ }^{5}$ It is possible that most projects are significantly better than some of the low-rent housing available on the private market—in New York City alone, 60,000 people live in private housing so unsafe that it is judged to endanger lives (Sontag, 1996). For many families in projects, the alternative may be moving from place to place as they seek affordable accommodations, interspersed with spells of homelessness. Children in these situations are often forced to change schools frequently, putting them at risk of grade repetition and poor academic achievement (General Accounting Office, 1994; Rubin et al., 1996). The fact that several large cities have long waiting lists for public housing projects also lends credence to the idea that projects may be viewed as better than available and affordable alternatives on the private market. ${ }^{6}$

Families are eligible for assistance if they have incomes at or below 50 percent of the area median. Housing authorities may also choose to allocate as many as 25 percent of their units to families with incomes between 50 percent and 80 percent of the area median. Thus, families in projects are selected because they are disadvantaged, something that must be kept in mind when housing quality and child outcomes are examined.

${ }^{5}$ The effects of neighborhoods remain controversial, although many studies have found that they are important. Wilson (1987) and Jencks and Mayer (1990) emphasize that bad neighborhoods may lack role models and desirable peers, as well as opportunities for education, recreation, and employment. Case and Katz (1991) provide some evidence that children in neighborhoods in which a large proportion of other children are involved in crime are more likely to be involved in crime themselves. Similar effects are found for drug and alcohol use and for idleness (i.e., being out of school and out of work). In a study of inner-city Chicago project residents who were allowed to apply for Section 8 housing certificates, Rosenbaum (1992) found that in families able to move to the suburbs, children were less likely to drop out of school and both mothers and children were more likely to be employed.

${ }^{6}$ New York City currently has approximately 340,000 families on waiting lists for housing assistance (Sontag, 1996). 
Families in projects have their rents capped at 30 percent of their income (after certain deductions are made), a regulation that complicates the interpretation of "rent" since families with more earnings will pay more. In fact, since the Census rent question is somewhat ambiguous, it is likely that some project families give the amount they actually pay while others attempt to estimate the rental value of their units. ${ }^{7}$ In any case, it is not uncommon for researchers using survey data to conclude that participation in housing programs increases rental payments. ${ }^{8}$ Hence, rather than focusing exclusively on rent, and assuming that reported rent is a good summary measure of housing quality, we examine overcrowding and density, two direct measures of housing quality, as well as grade repetition, a measure of children's educational attainment.

A good deal of evidence relates overcrowded conditions to ill health in children. Overcrowding leads to a higher incidence of respiratory illness (Mann, Wadsworth, and Colley, 1992) and of stomach infections (Galpin, Whitaker, and Dubiel, 1992), and Coggon et al. (1993) relate overcrowding to a higher probability of death from all causes in a sample of English children.

High-density residential complexes contribute to social malaise among their residents. Fischer and Baldassare (1975) state that density is disliked, makes most people uncomfortable, and reduces local

${ }^{7}$ On the 1990 Census form, respondents were instructed to classify their dwelling as "Rented for cash rent" if any money is paid, even if the rent is paid by persons who are not members of the household, or by a federal, state, or local government agency. Most project residents should be in this category. Other categories include: owned by respondent or by someone in the household with a mortgage or loan; owned by respondent or someone in the household free and clear (without a mortgage); and occupied without cash rent (e.g., tenant sharecroppers or military personnel). Renter respondents are given the following instructions. "Answer only if you pay rent for this house or apartment-what is the monthly rent?" The answer categories are: 0-\$80, $\$ 80-\$ 99, \$ 100-\$ 124$, $\$ 125-\$ 149, \ldots, \$ 525-\$ 549, \$ 550-\$ 599, \ldots, \$ 700-\$ 749, \$ 750-\$ 999$, and $\$ 1000$ or more. The supporting documentation (which is not on the questionnaire itself) explains, "Report the rent agreed to or contracted for, even if the rent for your house, apartment, or mobile home is unpaid or paid by someone else." It is not clear how a project resident would interpret this question. In 1990 the American Housing Survey (AHS) changed from asking a similar question about the monthly rent to asking about both the monthly contract rent and the rent actually paid by subsidized families. We find (using the Metropolitan Statistical Area sample) that among project residents in the 1990 to 1994 AHS, the mean contract rent was \$254 versus a mean amount actually paid of \$155 (nominal dollars).

${ }^{8}$ For example, Crews (1996), who uses data from the 1987 American Housing Survey, groups project and voucher recipients together and finds an increase in rental payments of about 4 percent. 
social interaction. This malaise may be linked to higher crime rates. For example, Condon (1991) finds that crime rates were lower in low-rise buildings than in high-rise buildings in the same Chicago projects. Atlas and Dreier (1993) cite similar evidence for New York showing that crime rates are lower in low-rise projects. In any case, HUD is actively engaged in replacing the most notorious large high-rise public housing complexes with low-rise "garden" apartments. For example, two high-rises in the Henry Horner Homes in Chicago, the setting for Alex Kotlowitz's shocking book There Are No Children Here (1991), are being demolished and will be replaced by 700 townhouses to be located throughout Chicago's west side (HUD, 1996).

The measure of schooling attainment we use is whether a child has been held back one grade or more. Academic performance in early grades has been shown to be a significant predictor of eventual high school completion (e.g., Barrington and Hendricks, 1989; Cairns, Cairns, and Neckerman, 1989; Grissom and Shepard, 1989; Ensminger and Slusarcick, 1992), which in turn is linked to future employment probabilities and earnings. Thus, our three outcome measures are intended to capture important dimensions of child well-being that may be affected by public housing, including health, exposure to crime, and academic achievement.

\section{METHODS}

Two important empirical problems face us. The first is that the outcomes we examine are recorded in the Census data, but the Census does not have information about whether a family lives in a public housing project, the key right-hand-side variable of interest. One approach to this problem is to use data from a second source to impute a probability of living in public housing to each family. We use data from the HUD's A Picture of Subsidized Housing (HUD, 1997) for this purpose. 
This data set provides cross-sectional information at the individual project level about the fraction of project residents who fall into various race, income, age, and marital status categories, and it also gives the number of units in the project. All the information pertains to 1995-96. We use this information to form a rough estimate of the number of project units in each Metropolitan Statistical Area (MSA) that are allocated to families in each of a number of income/race/age/marital status/size-ofbuilding categories, as described in the Appendix. We then use the Census data to calculate the number of families living in apartments in each MSA that fall into each category. Dividing the first number by the second gives us an estimate of the fraction of households of a particular type living in projects in each MSA.

Table 1 illustrates the variation in this measure for two MSAs, Boston and Chicago. The table shows that the probability of living in a project varies considerably with income and with demographic characteristics. For example, in Boston, an unmarried parent with an income between $\$ 5,000$ and $\$ 20,000$ who is living in a complex with over 50 units is very likely to be living in a project. The table also illustrates that much of the variation in this constructed measure occurs across MSAs. In Chicago, the probability that the household described above lives in a project ranges from 24 percent to 39 percent depending on race and income.

We include this noisy measure of the probability of living in a project (PROJ\%) in an ordinary least squares (OLS) regression of the form:

$$
\text { OUTCOME }=\alpha_{0}+\alpha_{1} \text { PROJ } \%+\alpha_{2} \mathrm{X}+\mathrm{u},
$$

where the OUTCOME variables include measures of housing overcrowding, density, and grade repetition, which are discussed in greater detail below, and $\mathrm{X}$ is a vector of additional exogenous explanatory variables including controls for the household head's gender, age, race, education, and marital status. When OUTCOME refers to child educational attainment, dummy variables for the child's age and sex are also included in X. This procedure gives a baseline estimate of the effect of projects on 
TABLE 1

Imputation of Public Housing Participation Rates for Renters, Where the Head Is Aged 25 to 44

\begin{tabular}{|c|c|c|c|c|c|c|c|c|}
\hline & \multicolumn{4}{|c|}{ Head Is Minority } & \multicolumn{4}{|c|}{ Head Is Not Minority } \\
\hline & $\begin{array}{c}\$ 0 \leq \\
\text { Income } \\
<\$ 5000\end{array}$ & $\begin{array}{c}\$ 5000 \leq \\
\text { Income } \\
<\$ 10,000\end{array}$ & $\begin{array}{c}\$ 10,000 \leq \\
\text { Income } \\
<\$ 20,000\end{array}$ & $\begin{array}{c}\text { Income } \\
\geq \$ 20,000\end{array}$ & $\begin{array}{c}\$ 0 \leq \\
\text { Income } \\
<\$ 5000\end{array}$ & $\begin{array}{c}\$ 5000 \leq \\
\text { Income } \\
<\$ 10,000\end{array}$ & $\begin{array}{c}\$ 10,000 \leq \\
\text { Income } \\
<\$ 20,000\end{array}$ & $\begin{array}{l}\text { Income } \\
\geq \$ 20,000\end{array}$ \\
\hline \multicolumn{9}{|l|}{ Boston MSA } \\
\hline Unmarried, $<50$ units & .0005 & .0114 & .0070 & .0027 & .0000 & .0063 & .0066 & .0010 \\
\hline Unmarried, 50+ units & .3606 & 1.0000 & 1.0000 & .1383 & .2820 & 1.0000 & .7927 & .2237 \\
\hline Married, <50 units & .0000 & .0082 & .0045 & .0007 & .0000 & .0098 & .0036 & .0001 \\
\hline Married, 50+ units & .0283 & 1.0000 & .2153 & .0147 & .0454 & .0000 & .7419 & .0099 \\
\hline \multicolumn{9}{|l|}{ Chicago MSA } \\
\hline Unmarried, $<50$ units & .0016 & .0018 & .0017 & .0004 & .0006 & .0013 & .0011 & .0001 \\
\hline Unmarried, 50+ units & .9880 & .3685 & .3937 & .0452 & .6666 & .3066 & .2444 & .0027 \\
\hline Married, $<50$ units & .0003 & .0007 & .0002 & .0001 & .0000 & .0022 & .0006 & .0001 \\
\hline Married, 50+ units & .2847 & .1414 & .0284 & .0013 & .0000 & .0555 & .0119 & .0000 \\
\hline
\end{tabular}

Notes: Those in the Census who report being a homeowner receive a probability of zero. When an imputed probability is greater than 1 , it is rounded down to 1.0000 . 
outcomes. Note that it is likely to be biased toward zero by random measurement error in our imputation procedure.

The second empirical problem is that whether a family lives in a project reflects choices made by both households and program administrators. Many unobserved factors, such as whether the family can double-up with friends and relatives or has recently been homeless, are likely to affect participation and outcomes. Thus, no matter how accurately we imputed whether a family lived in a project, OLS estimates obtained using these imputations would be subject to omitted variables bias. Our expectation is that omitted variables will bias the estimated effects of living in projects downward since families in projects may be more likely to live in substandard housing in any case, and their children may be more likely to experience negative outcomes. Other factors that may affect participation and outcomes are observed, but either poorly measured or also endogenous (e.g., income from other welfare programs).

We attempt to circumvent this selection problem by using an instrumental variables (IV) strategy. Under HUD rules, the sex composition of children in the household affects the number of bedrooms in the subsidized unit and therefore affects the size of the subsidy the family is eligible for. Except in the case of very young children, boys and girls cannot be required to share bedrooms, and no more than two children are allowed per bedroom. ${ }^{9}$ Thus, a family with two boys would be eligible for a two-bedroom apartment while a family with a boy and a girl would be eligible for a three-bedroom apartment. In what follows, we restrict the analysis to families with exactly two related children under 18 in the household in order to focus on the effects of sex composition and abstract from any effects due to the number of children. Families eligible for larger apartments (i.e., higher subsidies) should be more likely to live in public housing projects, other things being equal.

${ }^{9} \mathrm{HUD}$ requires that "The dwelling unit shall contain at least one bedroom or living/sleeping room of appropriate size for each two persons. Persons of opposite sex, other than husband and wife or very young children, shall not be required to occupy the same bedroom or living/sleeping room" (HUD, 1993: 188). This rule appears to have been in effect at least since the early 1980s. 
For sex composition to be a valid instrument, it must also be the case that it has no independent effect on our outcome measures, however. There is little reason to expect that sex composition will affect overcrowding (at least as we define it below) or density. But there is controversy in the literature about whether sex composition affects educational attainment. Butcher and Case (1994) argue that for girls, the presence of any sisters reduces educational attainment. They find no effect of sex composition among boys. A closer inspection of their reported findings indicates that in two-child families, significant sex composition effects are found only in the Panel Study of Income Dynamics and not in the Current Population Survey or National Longitudinal Survey of Women data sets. Kuo and Hauser (1996) argue that it is difficult to find any consistent effect of sex composition on educational attainment, while Kaestner (1997) is unable to replicate the Butcher and Case findings using the National Longitudinal Survey of Youth (NLSY). It is possible that their result holds for older cohorts but not for the younger group observed in the NLSY.

All of these studies focus on completed educational attainment. Perhaps sex composition has no effect on the probability of being held back but does have some small effect on girls' completed years of schooling. In any case, we will keep the Butcher and Case (1994) results in mind and report below the effects of project participation on the probability that boys are held back-if sex composition matters only for girls, then sex composition should be a valid instrument in a sample of boys. ${ }^{10}$

Our method of imputing the probability of public housing participation from the HUD data made no use of the sex composition of children in the household, since this is not recorded in A Picture of Subsidized Housing (HUD, 1997). Thus, other things being equal, a family with a boy and a girl and a family with two boys will have the same imputed probability of living in a project, and our proposed

\footnotetext{
${ }^{10}$ See Angrist and Evans (1996) for use of this sex composition instrument in another setting.
} 
instrument is orthogonal to PROJ\%. Hence, we cannot estimate (1) using standard IV techniques and we turn to the TSIV approach.

As discussed in Angrist and Krueger $(1992,1995)$, TSIV is appropriate in situations in which the outcomes are available in one data set, the endogenous regressor is available in a second data set, and both data sets contain the instrumental variable and the other exogenous variables included in the model. We use the March CPS as the second data set. It contains information about whether the family lives in a public housing project, about the sex composition of the children in the household, and about a wealth of other potential control variables, such as parental education, which are expected to influence outcomes.

In our application, the TSIV method involves estimating the first-stage equation predicting project residence using the CPS:

$$
\text { PROJECT }=\beta_{0}+\beta_{1} \text { EXTRA }+\beta_{2} X+v,
$$

where PROJECT is a dummy variable equal to one if the family lives in a project, and EXTRA is a dummy variable equal to one if the family has a boy and a girl and equal to zero if they have two boys or two girls.

In the second stage, the estimated coefficients from the first stage are used to predict project residence, PROJECT $^{*}$ in the Census data, and this predicted probability is included in models of outcomes estimated using Census data:

$$
\text { OUTCOME }=\gamma_{0}+\gamma_{1} \text { PROJECT }^{*}+\gamma_{2} \mathrm{X}+\epsilon
$$

The standard errors are then corrected to account for the fact that a predicted value of PROJECT is used in the second stage. Angrist and Krueger $(1992,1995)$ show that this procedure produces consistent estimates of the effect of the endogenous variable, PROJECT. 


\section{DATA}

The outcomes we focus on are recorded in the 1990 Census 1 percent and 5 percent Public Use Microdata Samples (PUMS). The Census asks about characteristics of the housing occupied by households. We focus on two variables: whether the family lives in high-density housing, defined as a building with over 50 units, and whether the family is overcrowded, which we define as having a greater number of family members than the number of bedrooms/living rooms plus one. ${ }^{11}$ Unfortunately, the smallest geographical unit identified in the PUMS is the MSA, so it is not possible to look at the effects of project participation on neighborhood characteristics.

The Census does not ask about grade repetition per se but does ask about children's educational attainment. The answers are grouped as follows: nursery school, kindergarten, grades 1 to 4 , grades 5 to 8 , grade 9 , grade 10 , grade 11 , and higher grades (which are not relevant for our purposes). We define children as having been "held back" at least one grade if they are 6 years old and have not completed nursery school; if they are 7 years old and have not completed kindergarten; if they are 8 to 11 years old and are not in at least grades 1 to 4; if they are 12 to 15 years old and are not in at least grades 5 to 8 ; if they are 16 years old and have not completed grade 9; and if they are 17 years old and have not yet completed grade 10 .

Because grades are grouped together, the probability of being held back varies with the child's age-for example, as shown in Appendix Table 3, we classify 4.5 percent of 8-year-olds as being held back, but less than 1 percent of 11-year-olds because we cannot distinguish in the data between an 11year-old in grade 4, and an 11-year-old in grade 1 or 2 . Only 11-year-olds who are lagging very far

\footnotetext{
${ }^{11} \mathrm{We}$ focus on families that are severely overcrowded in order to avoid picking up a relationship between crowding and sex composition of the children that is not due to incentives for participation in public housing. Suppose, for example, that a family with a married couple and one boy lived in a two-bedroom apartment (one bedroom plus one living room). They would not be classified as overcrowded. If the couple had a second boy, they might choose to remain in the same apartment, whereas if they had a girl, they might prefer to have a three-bedroom apartment. Our definition would treat the two families in the same way; neither would be classified as overcrowded.
} 
behind (being in less than grade 1) can be classified for certain as "held back." The probability of being classified as held back rises to 6.1 percent for 12-year-olds and 6.7 percent for 16-year-olds, so our measure does rise with age as it should among children for whom "held back" is defined in approximately the same way. To deal with this measurement problem, we include single year-of-age dummies in the models of "held back." We also repeat our analyses for the subsample of children for whom "held back" is defined most similarly (8-, 12-, 16-, and 17-year-olds) and for a sample that excludes 6- and 7-year-olds, since among these children, low educational achievement may reflect delays in starting school rather than failure to complete a grade. Although the Census data on children's education are imperfect, they are better than those available in the CPS and the Survey of Income and Program Participation, which ask about education only for children 15 and older.

As discussed above, we focus on households with two related children under 18. A number of additional screens are applied to the Census data. We exclude individuals in households with members over 61 years old, since they may be eligible for public housing because of their age. We also exclude individuals without a uniquely identified MSA, since it is not possible to match them to the HUD data. In fact, since we go on to match Census data with information from the CPS, we focus on the subset of MSAs that are identified in the CPS. ${ }^{12}$ This restriction has the effect of eliminating project residents in some smaller towns from our sample. But anecdotal evidence and HUD evaluations suggest that it is the largest projects that are most troubled, and these projects are unlikely to be located in small urban areas. Hence, this sample restriction is likely to exaggerate any negative effects of projects.

We also restrict attention to households in which the head and spouse (if present) are over 17 years old. Finally, we restrict attention to household heads in order to arrive at one observation per

\footnotetext{
${ }^{12}$ The CPS identifies the 113 largest MSAs, plus 89 selected MSAs and 66 selected Primary MSAs.
} 
family for our analysis of housing characteristics. We call the resulting 442,447 households the "housing sample."

The sample we use for examining educational attainment is somewhat different, since the unit of observation is the child, and the children must be between 6 and 17 years old, inclusive. Applying these tests results in a "child sample" of 562,218 children in 341,321 households. Appendix Table 1 shows the number of observations lost as each screen is applied.

Table 2 shows the means of the outcome variables in the Census data by imputed participation rates. The first column comprises primarily people who we know are not living in projects because they own their own home. The second column is composed of renters whom we judge to have a very low probability of living in a project given their own demographic characteristics and the composition of the housing projects in their MSA. The third column contains the relatively few people who have a higher probability of living in a project. The table shows that rent falls as the probability of living in a project rises, as does the probability of living in overcrowded or dense conditions and the probability that a child has been held back. Thus, these raw means suggest the possibility that families sacrifice both housing quality and at least some child outcomes in order to take advantage of lower rental payments in projects. Families in projects are also more likely to be headed by single parents, blacks, and persons with less than a high school education.

The CPS sample for estimating the first-stage equations is drawn from the pooled 1990 to 1995 March surveys. Applying essentially the same screens as with the Census data results in a "housing sample" of 32,098 households and a "child sample" of 39,935 children. The number of observations lost when each screen is applied is shown in Appendix Table 2.

In view of the move toward certificate and voucher programs noted in the introduction, it would be instructive to examine the effects of these programs. Our focus on participation in projects is dictated by the limitations of the CPS data on public housing participation. The fundamental problem is that the 
TABLE 2

Variable Means Based on Imputed Participation Rates (Standard Errors)

\begin{tabular}{|c|c|c|c|c|c|c|}
\hline \multirow[b]{2}{*}{ Imputed participation rate } & \multicolumn{2}{|c|}{$\begin{array}{c}\text { Project } \\
\text { Participation }=0\end{array}$} & \multicolumn{2}{|c|}{$\begin{array}{c}0<\text { Project } \\
\text { Participation }<.05 \\
\end{array}$} & \multicolumn{2}{|c|}{$\begin{array}{c}\text { Project } \\
\text { Participation } \geq .05 \\
\end{array}$} \\
\hline & 0 & $(0)$ & .004 & $(.000)$ & .325 & $(.006)$ \\
\hline Child held back & .031 & $(.000)$ & .042 & $(.000)$ & .048 & $(.003)$ \\
\hline Monthly rental payment/1000 & .604 & $(.001)$ & .521 & $(.001)$ & .379 & $(.003)$ \\
\hline Family is overcrowded & .030 & $(.000)$ & .089 & $(.001)$ & .119 & $(.005)$ \\
\hline Dense building & .005 & $(.000)$ & .050 & $(.000)$ & .673 & $(.007)$ \\
\hline Head's age & 37.801 & $(.012)$ & 34.133 & $(.030)$ & 35.205 & $(.169)$ \\
\hline Head married & .869 & $(.000)$ & .419 & $(.002)$ & .219 & $(.007)$ \\
\hline Head female & .106 & $(.000)$ & .511 & $(.002)$ & .724 & $(.007)$ \\
\hline Head black & .084 & $(.000)$ & .323 & $(.001)$ & .462 & $(.008)$ \\
\hline Head other & .082 & $(.000)$ & .185 & $(.001)$ & .244 & $(.007)$ \\
\hline Head Hispanic origin & .088 & $(.000)$ & .242 & $(.001)$ & .305 & $(.007)$ \\
\hline $9 \leq$ Head's education $\leq 11 \mathrm{yr}$. & .091 & $(.000)$ & .218 & $(.001)$ & .306 & $(.007)$ \\
\hline Head's education $=12 \mathrm{yr}$. & .253 & $(.000)$ & .308 & $(.001)$ & .295 & $(.007)$ \\
\hline $13 \leq$ Head's education $\leq 15 \mathrm{yr}$. & .304 & $(.000)$ & .274 & $(.001)$ & .217 & $(.007)$ \\
\hline Head's education $\geq 16 \mathrm{yr}$. & .313 & $(.000)$ & .106 & $(.001)$ & .058 & $(.003)$ \\
\hline Number of family members & 4.122 & $(.001)$ & 3.823 & $(.003)$ & 3.640 & $(.014)$ \\
\hline Number of observations & 379 & & & & & 450 \\
\hline
\end{tabular}

Note: For variables dealing with children (held back), means and standard errors drawn from the "child sample"; otherwise, means and standard errors from "housing sample." 
CPS asks specifically about projects ("Is this house in a public housing project, that is, is it owned by a local housing authority or other public agency?") but is not very specific when asking about participation in other types of public housing programs ("Are you paying lower rent because the federal, state, or local government is paying part of the cost?"). The second question covers Section 8 Certificate and Voucher Programs, but it also covers Section 8 Moderate Rehabilitation, and Section 8 New, and Substantive Rehabilitation Programs as well as various other subsidy programs. Administrative data from A Picture of Subsidized Housing (HUD, 1997) indicate that fewer than half the households answering "Yes" to the second program are likely to be participating in certificate or voucher programs.

It might still be the case, however, that the MSA-level variation in the fraction of households answering "Yes" to the rent subsidy question is driven by differences in participation rates in the voucher program across MSAs. However, when we examined this correlation, we found little evidence of a relationship. In contrast, a strong cross-MSA correlation exists between the fraction participating in projects in the CPS data and the fraction participating in projects in the HUD data. Thus, the CPS questions are appropriate for looking at project participation but not for identifying the effects of voucher programs. ${ }^{13}$

A second limitation of the CPS participation data is that they refer to whether a household was living in public housing in March of the survey year. The effects of public housing on schooling attainment cannot be expected to be instantaneous - thus, our estimates of the effects of participation on the probability of being held back are meaningful only if current residence in a project is a marker for probable longer-term residence. The HUD administrative data speak to this issue- the average length of

\footnotetext{
${ }^{13}$ It is also possible that some households participating in voucher programs are wrongly classified as participating in projects (though we feel that the CPS question is very clear about what a project is). In this case, what we identify as project effects might in reality be effects of voucher programs. To address this problem, we tried limiting the sample to MSAs in which the administrative data indicated that a relatively high proportion of public housing units were located in projects. Unfortunately, the variation in the fraction of units located in projects is not high—ranging from about 40 percent to about 60 percent across most MSAs. Thus, this experiment reduced our sample size without eliminating much if any reporting error.
} 
time since the household moved in is 7 years with a standard deviation of about 5 years, and the average total stay of households is 12 years.

The first two columns of Table 3 show means of the CPS data used to estimate the first stage by whether the household lives in a project. A comparison of columns 1 and 2 indicates that households living in projects are more likely to be eligible for an extra bedroom: 54 percent of these households have a boy and a girl versus 50 percent of households outside of projects. Table 3 also confirms that, as discussed above, households in projects are likely to be disadvantaged along a number of observable dimensions.

The next four columns of Table 3 divide the CPS and Census samples by whether the family is entitled to an extra bedroom. The families in columns 3 and 5 have a boy and a girl, while families in columns 4 and 6 have either two boys or two girls. The raw CPS data in the first row show that families entitled to an extra bedroom are 17 percent more likely to live in a project. However, the remainder of the table shows that these families also differ from other families in some respects-in particular, they are less likely to be female-headed. Differences in the observable characteristics of families will be controlled for in the model estimated below.

Finally, a comparison between the CPS figures in columns 3 and 4 of Table 3 and the Census figures in columns 5 and 6 suggests only slight differences between the two samples. One exception is that the Census families are less likely to be female-headed and less likely to be classified as Hispanic than as "other origin."14

\footnotetext{
${ }^{14}$ There is some discrepancy between the CPS and Census figures in the number of married/spouse present households who report that the household head is female (94 percent in the Census versus 89 percent in the pooled CPS sample). Hence, to use the same definition of "female-headed" in the two samples, we have adopted the conservative strategy of assuming that the household head is male in these cases. Hispanic is derived from the "detailed Hispanic origin code" in the Census and from the "origin" code in the CPS. We coded any respondent who answered "yes" to Hispanic ethnicity as Hispanic regardless of racial origin (white/black/other).
} 
TABLE 3

Variable Means (Standard Errors)

\begin{tabular}{|c|c|c|c|c|c|c|c|c|c|c|c|}
\hline & \multicolumn{4}{|c|}{ CPS } & \multicolumn{4}{|c|}{ CPS } & \multicolumn{3}{|c|}{ Census } \\
\hline & \multicolumn{2}{|c|}{ Projects $=1$} & \multicolumn{2}{|c|}{ Projects $=0$} & \multicolumn{2}{|c|}{$\begin{array}{c}\text { Extra } \\
\text { Bedroom }=1\end{array}$} & \multicolumn{2}{|c|}{$\begin{array}{c}\text { Extra } \\
\text { Bedroom }=0\end{array}$} & \multicolumn{2}{|c|}{$\begin{array}{c}\text { Extra } \\
\text { Bedroom }=1\end{array}$} & $\begin{array}{c}\text { Extra } \\
\text { Bedroom }=0\end{array}$ \\
\hline Participation in public housing & 1 & $(0)$ & 0 & $(0)$ & .036 & $(.001)$ & .030 & $(.001)$ & & - & - \\
\hline Extra bedroom & .543 & $(.015)$ & .495 & $(.002)$ & 1 & $(0)$ & 0 & (0) & 1 & $(0)$ & $(0)$ \\
\hline Child held back & & - & & - & & - & & - & .031 & $(.000)$ & $.033(.000)$ \\
\hline Monthly rental payment/1000 & & - & & - & & - & & - & .568 & $(.001)$ & $.558(.001)$ \\
\hline Family is overcrowded & & - & & - & & - & & - & .038 & $(.000)$ & $.040(.000)$ \\
\hline Dense building & & - & & - & & - & & - & .016 & $(.000)$ & $.017(.000)$ \\
\hline Child's age & 10.723 & $(.096)$ & 11.062 & $(.017)$ & 11.021 & $(.023)$ & 11.085 & $(.024)$ & 11.046 & $(.006)$ & $11.077(.006)$ \\
\hline Child is girl & .464 & $(.014)$ & .484 & $(.002)$ & .495 & $(.003)$ & .472 & $(.003)$ & .499 & $(.000)$ & $.472(.000)$ \\
\hline Head's age & 32.867 & $(.256)$ & 37.496 & $(.042)$ & 37.084 & $(.057)$ & 37.595 & $(.062)$ & 37.291 & $(.015)$ & $37.288(.016)$ \\
\hline Head married & .256 & $(.013)$ & .796 & $(.002)$ & .789 & $(.003)$ & .766 & $(.003)$ & .810 & $(.000)$ & $.797(.000)$ \\
\hline Head female & .729 & $(.013)$ & .180 & $(.002)$ & .191 & $(.003)$ & .206 & $(.003)$ & .161 & $(.000)$ & $.170(.000)$ \\
\hline Head black & .479 & $(.015)$ & .107 & $(.001)$ & .115 & $(.002)$ & .123 & $(.002)$ & .116 & $(.000)$ & $.122(.000)$ \\
\hline Head other & .062 & $(.007)$ & .054 & $(.001)$ & .055 & $(.001)$ & .054 & $(.001)$ & .097 & $(.000)$ & $.097(.000)$ \\
\hline Head Hispanic origin & .235 & $(.012)$ & .169 & $(.002)$ & .169 & $(.002)$ & .174 & $(.002)$ & .110 & $(.000)$ & $.111(.000)$ \\
\hline $9 \leq$ Head's education $\leq 11 \mathrm{yr}$. & .251 & $(.013)$ & .088 & $(.001)$ & .092 & $(.002)$ & .096 & $(.002)$ & .108 & $(.000)$ & $.111(.000)$ \\
\hline Head's education = $12 \mathrm{yr}$. & .416 & $(.015)$ & .319 & $(.002)$ & .317 & $(.003)$ & .328 & $(.003)$ & .261 & $(.000)$ & $.261(.000)$ \\
\hline $13 \leq$ Head's education $\leq 15 \mathrm{yr}$. & .193 & $(.012)$ & .252 & $(.002)$ & .255 & $(.003)$ & .245 & $(.003)$ & .299 & $(.000)$ & $.299(.000)$ \\
\hline Head's education $\geq 16$ yr. & .041 & $(.006)$ & .284 & $(.002)$ & .280 & $(.003)$ & .272 & $(.003)$ & .285 & $(.000)$ & $.281(.000)$ \\
\hline Number of family members & 3.409 & $(.019)$ & 3.991 & $(.003)$ & 3.946 & $(.004)$ & 3.997 & $(.005)$ & 4.077 & $(.001)$ & $4.080(.001)$ \\
\hline Number of observations & 1,0 & 074 & &, 024 & 15,9 & 47 & 16 & 151 & 227 & ,484 & 214,963 \\
\hline
\end{tabular}

Note: For variables dealing with children (held back, child's age, and child's gender), means and standard errors drawn from the "child sample"; otherwise, means and standard errors from "housing sample." 


\section{RESULTS}

\section{OLS Estimates Using Imputed Project Participation}

OLS estimates of equation (1) are shown in Table 4 for two outcome variables: whether the family is overcrowded and whether the child has been held back. Because we used housing density to impute the probability of project participation, density is mechanically related to PROJ\%, so this outcome is omitted from the table. Only the coefficients on PROJ\% are shown. Row 1 of Table 4 reports estimates from models without other covariates and confirms that, as one might expect on the basis of Table 2, families with a higher probability of participating in projects are more likely to suffer from overcrowding, and their children are more likely to have been held back in school.

Row 2 of Table 4 reports the coefficient on PROJ\% from models that include dummy variables for all the demographic and income categories used to construct the project participation rate. Hence these models identify the effects of projects by relying on cross-MSA variation in the availability of project units to households of different types. Controlling for demographic differences between project residents and other households in this way dramatically reduces the estimated effects of projects: The estimated effect of project residence on the probability that children are held back is reduced to statistical insignificance, although project residents are still slightly more likely to suffer from overcrowding.

Recall, as discussed above, that we expect measurement error in PROJ\% to bias these coefficients toward zero. Thus, the true OLS estimate of the effect of housing projects (i.e., what we would find in a data set that had both outcomes and project participation) may be more negative. A second problem is that if the placement and demographic composition of housing projects are endogenous or reflect characteristics of MSAs that are themselves correlated with our outcome measures (such as high poverty rates), then geographic variation in the character and availability of project units is not a legitimate source of identifying variation. It might be the case, for example, that MSA-level 
TABLE 4

OLS Results Using Imputed Project Participation Rates from HUD Data

Linked to Census PUMS Data (Standard Errors)

Family Is Overcrowded

Child Was Held Back

Without Covariates:

Imputed Participation Rate

$.1336 \quad(.0074)$

$.0284 \quad(.0077)$

Controlling for Demographic Categories:

Imputed Participation Rate

$.0267 \quad(.0067)$

$-.0094 \quad(.0076)$

Number of observations

Housing Sample

Child Sample 442,447

562,218

Note: Standard errors in column 2 are corrected for multiple children in same household. 
variation in PROJ\% was correlated with variation in school quality or the extent of racial segregation in

the housing market. Hence, we turn to TSIV to try to identify the "true" causal effect of project residence on outcomes.

\section{$\underline{\text { TSIV Estimates }}$}

The first-stage estimates of equation (2) are shown in Table 5 separately for renters only and for the full sample. Within each group, we also show estimates for the child sample and for the housing sample. In all four samples, the extra bedroom/sex composition variable is a highly significant determinant of project participation, with t-values ranging between 3 and 4 . To understand the magnitude of this effect, consider the coefficient estimate in column 3 (the housing sample, including both homeowners and renters). The baseline participation rate in projects is 3.35 percent, while the marginal effect of adding an extra bedroom is 0.80 percentage point. Thus, adding an extra bedroom increases the likelihood of project participation by 24 percent. The other controls included in the model indicate that participation declines with the age of the head, is much lower for married heads, and is highest among blacks and those with less than a high school education. The dummy variables for child age are not individually or jointly statistically significant, indicating that the probability of living in a project does not vary with child age.

TSIV estimates of equation (3) appear in Table 6 for the subsample of renters. We focus initially on this subsample so that we can follow the existing public housing literature and look at the estimated effect of project participation on reported rent. Column 1 of Table 6 shows that the effect is positive and statistically significant, suggesting that many households are reporting the rental value of their accommodations rather than what they actually pay. If this is the case, then the estimates in column 1 suggest that families in projects live in housing of better quality than the housing they would otherwise have inhabited. 
TABLE 5

Results from CPS First-Stage Regression on Public Housing Participation (Standard Errors)

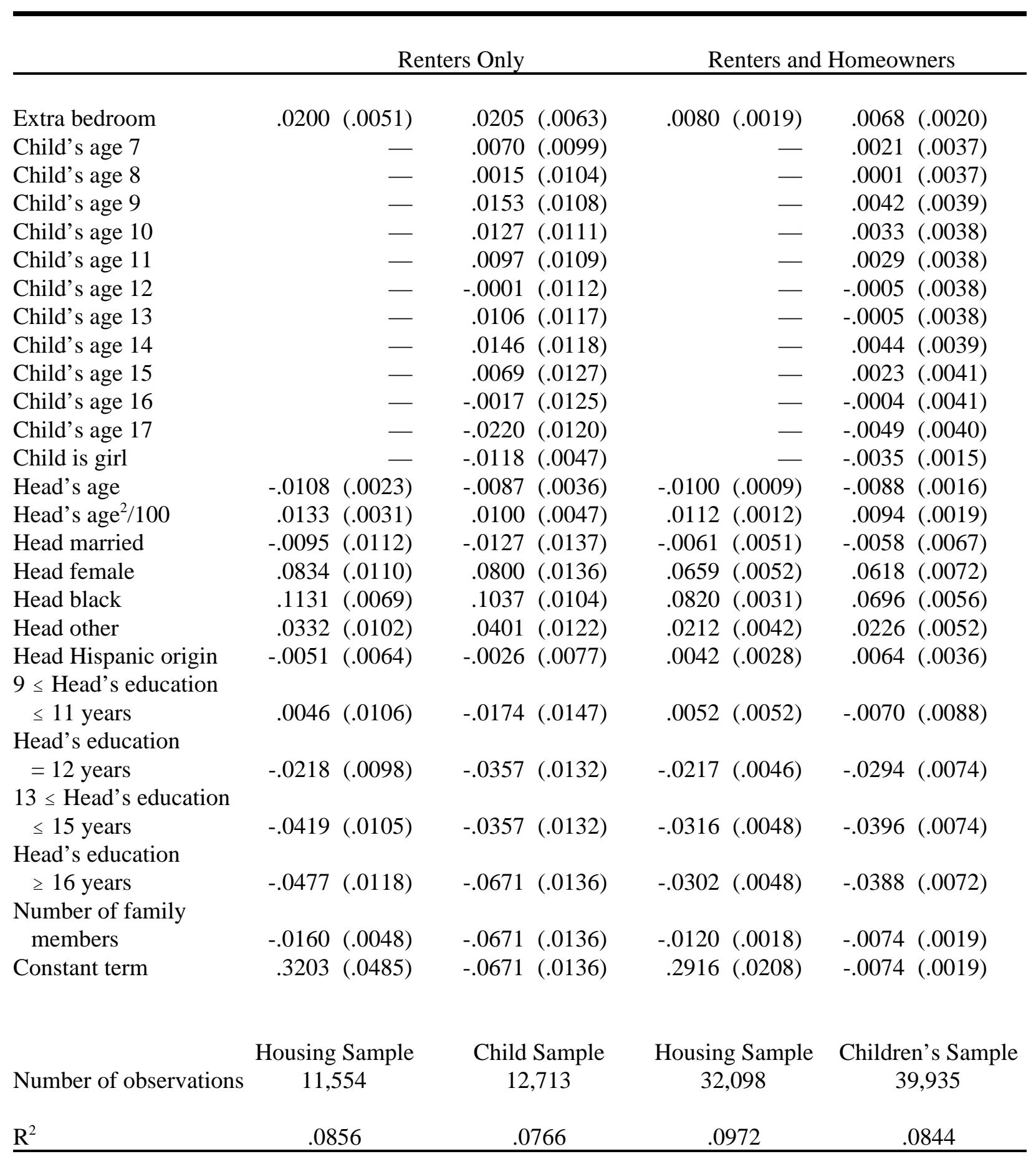

Note: Standard errors in the columns 2 and 4 are corrected for multiple children in same household. 
TABLE 6

Results from Census Using Two-Sample IV, Renters Only (Standard Errors)

\begin{tabular}{|c|c|c|c|c|}
\hline & $\begin{array}{c}\text { Monthly Rental } \\
\text { Payment/1000 }\end{array}$ & $\begin{array}{c}\text { Family Is } \\
\text { Overcrowded }\end{array}$ & Dense Building & $\begin{array}{l}\text { Child Was } \\
\text { Held Back }\end{array}$ \\
\hline $\begin{array}{l}\text { Participation in } \\
\text { public housing }\end{array}$ & $.4140(.0658)$ & $-.0691 \quad(.0689)$ & $-.0930(.0588)$ & $-.1237(.0501)$ \\
\hline Child's age 7 & - & - & - & $-.0597(.0024)$ \\
\hline Child's age 8 & - & - & - & $-.0391(.0026)$ \\
\hline Child's age 9 & - & - & - & $-.0613(.0025)$ \\
\hline Child's age 10 & - & 一 & 一 & $-.0745(.0022)$ \\
\hline Child's age 11 & - & 一 & - & $-.0745(.0022)$ \\
\hline Child's age 12 & - & - & - & $-.0109(.0031)$ \\
\hline Child's age 13 & - & - & - & $-.0525(.0026)$ \\
\hline Child's age 14 & - & - & - & $-.0642(.0025)$ \\
\hline Child's age 15 & - & - & - & $-.0711(.0023)$ \\
\hline Child's age 16 & - & 一 & - & $.0325(.0039)$ \\
\hline Child's age 17 & - & - & 一 & $.0712(.0044)$ \\
\hline Child is girl & - & - & - & $-.0108(.0011)$ \\
\hline Head's age & $.0239(.0009)$ & $-.0043(.0009)$ & $-.0019(.0008)$ & $-.0069(.0007)$ \\
\hline Head's age ${ }^{2} / 100$ & $-.0262(.0011)$ & $.0029(.0012)$ & $.0037(.0010)$ & $.0075(.0009)$ \\
\hline Head married & $.0121(.0030)$ & $-.0488(.0032)$ & $.0010(.0027)$ & $-.0131(.0026)$ \\
\hline Head female & $-.0890(.0063)$ & $-.0008(.0066)$ & $.0150(.0056)$ & $.0015(.0048)$ \\
\hline Head black & $-.1436(.0076)$ & $.0360(.0080)$ & $.0560(.0068)$ & $.0077(.0053)$ \\
\hline Head other & $-.0258(.0030)$ & $.1166(.0032)$ & $.0271 \quad(.0027)$ & $.0027(.0026)$ \\
\hline Head Hispanic origin & $-.0235(.0020)$ & $.0973(.0021)$ & $.0445(.0018)$ & $-.0036(.0016)$ \\
\hline $\begin{aligned} 9 & \leq \text { Head's education } \\
& \leq 11 \mathrm{yr} .\end{aligned}$ & $.0532(.0028)$ & $-.1011(.0029)$ & $.0164(.0025)$ & $-.0235(.0027)$ \\
\hline $\begin{array}{l}\text { Head's education } \\
=12 \mathrm{yr} \text {. }\end{array}$ & $.1029(.0031)$ & $-.1170(.0032)$ & $.0147(.0027)$ & $-.0314(.0031)$ \\
\hline $\begin{array}{l}13 \leq \text { Head's education } \\
\leq 15 \mathrm{yr} .\end{array}$ & $.1753(.0039)$ & $-.1189(.0041)$ & $.0167(.0035)$ & $-.0407(.0039)$ \\
\hline $\begin{array}{l}\text { Head's education } \\
\geq 16 \mathrm{yr} \text {. }\end{array}$ & $.3012(.0044)$ & $-.1099(.0046)$ & $.0353(.0039)$ & $-.0454(.0043)$ \\
\hline $\begin{array}{l}\text { Number of family } \\
\text { members } \\
\text { Constant term }\end{array}$ & $\begin{array}{rr}.0563 & (.0013) \\
-.2583 & (.0248)\end{array}$ & $\begin{aligned} .1231 & (.0014) \\
-.1877 & (.0260)\end{aligned}$ & $\begin{aligned}-.0061 & (.0012) \\
.0548 & (.0222)\end{aligned}$ & $\begin{array}{ll}.0051 & (.0010) \\
.2635 & (.0204)\end{array}$ \\
\hline Number of observations & $\begin{array}{c}\text { Housing Sample } \\
134,052\end{array}$ & $\begin{array}{c}\text { Housing Sample } \\
134,052\end{array}$ & $\begin{array}{c}\text { Housing Sample } \\
134,052\end{array}$ & $\begin{array}{c}\text { Child Sample } \\
160,174\end{array}$ \\
\hline $\mathrm{R}^{2}$ & .2147 & .2439 & .0155 & .0481 \\
\hline
\end{tabular}

Note: Standard errors in column 4 are corrected for multiple children in same household. 
This interpretation is supported by the point estimates in columns 2 and 3 of Table 6 , which show that these households are less likely to be overcrowded and also less likely to live in large, dense complexes, although these effects are not statistically significant. Finally, column 4 indicates that families in projects are not trading off physical housing amenities against other factors that harm child outcomes-children in the projects are 12 percentage points less likely to have been held back than children in other rental accommodation. The other demographic variables included in these models have the expected signs. Families whose heads are older, married, white, and better educated tend to have better outcomes, whether or not they live in projects. The child age dummies are individually statistically significant and pick up the pattern of classification error discussed above and documented in Appendix Table 3. For example, the estimated probability of being held back rises sharply between the ages of 11 and 12 , and then falls again until the child reaches age 16.

Table 7 repeats the TSIV analysis of the overcrowding, density, and grade repetition outcomes for the full sample of children. The estimates are qualitatively similar to those discussed above, but the point estimates are larger in absolute value, so that the results are stronger in terms of statistical significance. In our opinion, this specification is preferred because families choose whether to be renters or homeowners, and this choice may be influenced by public housing programs. These estimates suggest that when unobserved characteristics of families are controlled for, participation in projects has significantly positive effects on both housing quality and child outcomes.

As discussed above, there is some controversy in the literature about whether sex composition is a valid instrument for educational attainment, at least for girls. When we restrict the sample to boys only, the estimated reduction in the probability of being held back is -.25 with a standard error of .10 . For girls, the corresponding coefficient and standard error are -.09 and .09. Thus, it appears that the beneficial effects of projects on schooling attainment are confined to boys. 
TABLE 7

Results from Census Using Two-Sample IV, Renters and Homeowners (Standard Errors)

\begin{tabular}{|c|c|c|c|c|c|}
\hline & $\begin{array}{c}\text { Family Is } \\
\text { Overcrowded }\end{array}$ & \multicolumn{2}{|c|}{ Dense Building } & \multicolumn{2}{|c|}{$\begin{array}{l}\text { Child Was } \\
\text { Held Back }\end{array}$} \\
\hline Participation in public housing & $-.1030 \quad(.0642)$ & -.1318 & $(.0476)$ & -.1717 & $(.0719)$ \\
\hline Child's age 7 & - & & 一 & -.0512 & $(.0012)$ \\
\hline Child's age 8 & - & & - & -.0229 & $(.0014)$ \\
\hline Child's age 9 & - & & - & -.0457 & $(.0012)$ \\
\hline Child's age 10 & - & & - & -.0623 & $(.0011)$ \\
\hline Child's age 11 & - & & - & -.0621 & $(.0011)$ \\
\hline Child's age 12 & - & & - & -.0041 & $(.0015)$ \\
\hline Child's age 13 & - & & - & -.0418 & $(.0013)$ \\
\hline Child's age 14 & - & & - & -.0537 & $(.0012)$ \\
\hline Child's age 15 & - & & - & -.0595 & $(.0012)$ \\
\hline Child's age 16 & - & & - & .0018 & $(.0017)$ \\
\hline Child's age 17 & - & & - & .0188 & $(.0018)$ \\
\hline Child is girl & - & & - & -.0079 & $(.0005)$ \\
\hline Head's age & $-.0045(.0006)$ & -.0031 & $(.0005)$ & -.0063 & $(.0007)$ \\
\hline Head's age $/ 100$ & $.0025 \quad(.0007)$ & .0035 & $(.0005)$ & .0066 & $(.0008)$ \\
\hline Head married & $-.0585 \quad(.0015)$ & -.0073 & $(.0011)$ & -.0133 & $(.0017)$ \\
\hline Head female & $-.0024(.0045)$ & .0180 & $(.0033)$ & .0049 & $(.0047)$ \\
\hline Head black & $.0250 \quad(.0053)$ & .0416 & $(.0039)$ & .0115 & $(.0050)$ \\
\hline Head other & $.0852(.0016)$ & .0211 & $(.0012)$ & .0028 & $(.0018)$ \\
\hline Head Hispanic origin & $.0818 \quad(.0010)$ & .0281 & $(.0007)$ & -.0008 & $(.0011)$ \\
\hline $9 \leq$ Head's education $\leq 11 \mathrm{yr}$. & $-.0970 \quad(.0015)$ & .0056 & $(.0011)$ & -.0175 & $(.0018)$ \\
\hline Head's education $=12 \mathrm{yr}$. & $-.1191(.0019)$ & -.0020 & $(.0014)$ & -.0307 & $(.0026)$ \\
\hline $13 \leq$ Head's education $\leq 15 \mathrm{yr}$. & $-.1213(.0024)$ & -.0037 & $(.0018)$ & -.0367 & $(.0032)$ \\
\hline Head's education $\geq 16 \mathrm{yr}$. & $-.1179(.0024)$ & -.0007 & $(.0017)$ & -.0381 & $(.0032)$ \\
\hline Number of family members & $.0867 \quad(.0008)$ & -.0048 & $(.0006)$ & .0040 & $(.0007)$ \\
\hline Constant term & $-.0384(.0198)$ & .1008 & $(.0146)$ & .2416 & $(.0207)$ \\
\hline Number of observations & $\begin{array}{c}\text { Housing Sample } \\
442,447\end{array}$ & $\begin{array}{r}\text { Housin } \\
44\end{array}$ & $\begin{array}{l}\text { g Sample } \\
2.447\end{array}$ & Child & Sample \\
\hline $\mathrm{R}^{2}$ & .2146 & & 197 & & 284 \\
\hline
\end{tabular}

Note: Standard errors in column 3 are corrected for multiple children in same household. 
We also repeat our analyses for the subsample of children for whom "held back" is defined most similarly (8-, 12-, 16-, and 17-year-olds). The estimated effects of projects on the probability of being held back are stronger, which might be expected given that in this subsample, the probability of being correctly classified as being held back is much higher. The coefficient increases to -.76 with a standard error of .41. In addition, we re-estimate the model excluding 6- and 7-year-olds, because for these children, low educational achievement may reflect delays in starting school rather than failure to complete a grade. Restricting the sample in this way results in a coefficient estimate of -.17 with a standard error of .08 , which is nearly identical to that obtained using the full sample.

Finally, in Appendix Table 4 we explore the robustness of our estimates to some additional changes in specification. In particular, we show that our results are not sensitive to the inclusion of family income or to the exclusion of variables measuring family structure and marital status. The point estimates and standard errors are very similar to those reported in the main tables. We also show that the effects of public housing are largest when the head has low educational attainment, as one might expect if our estimates are really picking up the effects of housing programs.

\section{DISCUSSION AND CONCLUSIONS}

Although it is widely assumed that public housing projects are bad for children, little empirical research has been conducted on this question. A likely reason is that few large data sets combine information about project participation, housing quality, and child outcomes. In this paper, we combine information from several sources to take a first look at the effects of project participation on housing quality and on educational attainment, a critical child outcome.

In view of the negative public image of public housing projects, our results are surprising. While the correlation between project participation and the outcomes we examine is negative, we conclude that 
this is due to unmeasured characteristics of project participants. When these characteristics are controlled for using TSIV techniques, we find that projects actually have positive effects on both housing quality and children's academic achievement, suggesting that project families are not in fact forced to choose between the two. These results do not imply that the recent shift away from projects is misguided. It is possible, for example, that these same children would be better served by a voucher program. ${ }^{15}$ But the results do suggest that projects as a group have been wrongly vilified. Atlas and Dreier (1993) point out that "Public housing seems to many Americans a metaphor for the failures of activist government," but perhaps they are correct that in reality "the best kept secret about public housing is that most of it actually provides decent affordable housing to many people."

One important limitation of our work is that we are unable to assess the effects of participation in projects on neighborhood quality because the Census Public Use Microdata Samples do not contain Census tract or county identifiers. Linking geographic information of this kind to our data would allow a more direct test of hypotheses about the relationship between housing projects and neighborhoods.

\footnotetext{
${ }^{15}$ This question is the subject of ongoing research (e.g., Katz, Kling, and Leibman, 1997).
} 


\section{APPENDIX \\ Imputing Public Housing Participation Rates to Demographic Groups}

We review here the construction of PROJ\%, the imputed probability of participating in a project based on demographic category, socioeconomic status, and MSA. PROJ\% is defined as $\mathrm{PROJ}_{\mathrm{d}, \mathrm{m}, \mathrm{u}} / \mathrm{HH}_{\mathrm{d}, \mathrm{m}, \mathrm{u}}$, where PROJ is the number of project units allocated to demographic group $d$ in MSA $m$ in developments of size $u$ (where the size $u$ is either greater or less than 50 units), and HH is the total number of renter households in demographic group $d$ in MSA $m$ who live in apartments units of size $u$. This variable PROJ\% is used in Tables 1, 2, and 4. At the project level, A Picture of Subsidized Housing (HUD, 1997) gives data on the demographic characteristics of housing recipients, the total number of units in the projects, and the MSA location. These data were collected by HUD between October 1995 and September 1996. The first of 83 developments from the Boston MSA with valid demographic data look like this:

Sample Line from A Picture of Subsidized Housing (Age, Race, and Marital Status Refer to Household Head, While Income Refers to Entire Household)

\begin{tabular}{|c|c|c|c|c|}
\hline $\begin{array}{l}\text { Total units in } \\
\text { development }\end{array}$ & $\begin{array}{c}\% \text { Head under } \\
\text { age } 25\end{array}$ & $\begin{array}{c}\% \text { Head aged } 25 \\
\text { to } 44\end{array}$ & $\begin{array}{c}\% \text { Head aged } 45 \\
\text { to } 61\end{array}$ & $\begin{array}{c}\% \text { Head over } \\
\text { age } 61\end{array}$ \\
\hline 162 & 8 & 45 & 32 & 15 \\
\hline$\%$ Minority & $\%$ White & $\begin{array}{l}\% \text { Unmarried, } \\
\text { with kids }\end{array}$ & $\begin{array}{l}\% \text { Married, } \\
\text { with kids }\end{array}$ & $\%$ No kids \\
\hline 98 & 2 & 50 & 4 & 46 \\
\hline $\begin{array}{c}\% \mathrm{HH} \mathrm{w} / \mathrm{Inc} \\
<\$ 5,000\end{array}$ & $\begin{array}{c}\% \mathrm{HH} \mathrm{w} / \$ 5000 \leq \\
\mathrm{Inc}<\$ 10,000\end{array}$ & $\begin{array}{c}\% \mathrm{HH} \mathrm{w/} \\
\$ 10,000 \leq \mathrm{Inc} \\
<\$ 20,000\end{array}$ & $\begin{array}{c}\% \mathrm{HH} \mathrm{w} / \mathrm{Inc} \\
\geq \$ 20,000\end{array}$ & MSA identifier \\
\hline 6 & 59 & 22 & 13 & 1120 \\
\hline
\end{tabular}

To allocate units from a project to a demographic group (and thus construct $\mathrm{PROJ}_{\mathrm{d}, \mathrm{m}, \mathrm{u}}$, our procedure multiplies the number of units by the fraction of that age group, race group, marital status group, and income group in a project. Thus, for minority, single-parent households with heads between 
the ages of 25 and 44 and household incomes between $\$ 5,000$ and $\$ 10,000$, our procedure allocates 21.07 units $\left(162 * .45^{*} .98 * .50 * .59\right)$ to them. We carry out a similar computation for the other demographic groups used in our analysis and for the remaining developments within the MSA. By adding up across all developments with total units greater than 50, we obtain $\mathrm{PROJ}_{\mathrm{d}, \mathrm{m}, \mathrm{u}}$ for this specific group. In the entire sample, 9,729 of the 13,537 developments had valid data on demographic characteristics, representing 998,032 project units (out of a national total of 1,326,224 units). Of the 9,729 developments, 5,721 were large (containing more than 50 total apartment units); these large developments included 88 percent of the total apartment units.

To compute the denominator, $\mathrm{HH}_{\mathrm{d}, \mathrm{m}, \mathrm{u}}$, we use the 1990 Census PUMS 5 percent sample. For each household in the Census, we take the following variables: household weight; tenure status (homeowner vs. renter); head's age, race, marital status, and number of children; household income (inflated to 1996 dollars); MSA; and number of units in apartment complex. We then exclude households who are homeowners, households without children, and households where the head is under age 18 or over age 61. Using the remaining variables for renter households, we create 3 groupings for age $(18-24,25-44$, and 45-61), 2 for race (minority or nonminority), 2 for family structure (married with children or unmarried with children), 4 for income levels (given above), and 2 for unit size (50 or more units and less than 50 units). From these 96 demographic groupings in each MSA, we add up the household weights to construct $\mathrm{HH}_{\mathrm{d}, \mathrm{m}, \mathrm{u}}$.

Using the numerator from HUD data and the denominator from Census data, we compute PROJ\%. In cases where PROJ ${ }_{\mathrm{d}, \mathrm{m}, \mathrm{u}}$ was greater than $\mathrm{HH}_{\mathrm{d}, \mathrm{m}, \mathrm{u}}$, we impute PROJ\% to be 100 percent. Finally, for each observation in the microdata sample (see Appendix Table 2), we merge PROJ\% based on the appropriate demographic and socioeconomic variables and MSA. For households who report being homeowners, PROJ\% is imputed as 0 percent. 
APPENDIX TABLE 1

Sample Screens from Census, 1990

Census $1 \%$ Public Use Microdata Sample
Census 5\% Public Use Microdata Sample

1. Initial number of person records

$2,500,052$

$12,501,046$

2. Household has 2 related children under age 18

520,418

$2,598,587$

3. Uniquely identified state

511,364

$2,598,587$

4. Uniquely identified MSA

352,619

$1,654,325$

5. One of the MSAs identified in CPS data

339,121

$1,597,877$

6. No household member is over age 61

318,804

$1,501,426$

7. Household spouse is over age 17 (if present)

318,738

$1,500,979$

8. Observation is household head

78,240

368,124

9. Head is over age 17

78,222

368,034

10. Valid age given for spouse, if head is married

77,523

364,924

Line 10 gives a total of 442,447 households that are used in the "housing sample."

11. Number of related children, ages 6 to 17

98,607

463,611

Line 11 gives a total of 562,218 children (341,321 households) who are used in the "child sample."

Note: When both a husband and wife were present, we assigned the husband as the "household head." 
APPENDIX TABLE 2

Sample Screens from March Current Population Survey, 1990 to 1995

\begin{tabular}{|c|c|c|c|c|c|c|}
\hline & $\begin{array}{c}\text { March } \\
1990\end{array}$ & $\begin{array}{c}\text { March } \\
1991\end{array}$ & $\begin{array}{c}\text { March } \\
1992\end{array}$ & $\begin{array}{c}\text { March } \\
1993\end{array}$ & $\begin{array}{c}\text { March } \\
1994\end{array}$ & $\begin{array}{c}\text { March } \\
1995\end{array}$ \\
\hline $\begin{array}{l}\text { 1. Initial number of person } \\
\text { records }\end{array}$ & 158,079 & 158,477 & 155,796 & 155,197 & 150,943 & 149,642 \\
\hline \multicolumn{6}{|l|}{ 2. Household has 2 related } & 32,292 \\
\hline 3. Uniquely identified MSA & 22,799 & 22,838 & 22,190 & 22,385 & 22,329 & 21,850 \\
\hline $\begin{array}{l}\text { 4. No household member is } \\
\text { over age } 61\end{array}$ & 22,064 & 22,073 & 21,407 & 21,677 & 21,504 & 21,059 \\
\hline $\begin{array}{l}\text { 5. Household spouse is over } \\
\text { age } 17 \text { (if present) }\end{array}$ & 22,060 & 22,069 & 21,403 & 21,673 & 21,494 & 21,049 \\
\hline 6. Observation is household head & 5,455 & 5,451 & 5,291 & 5,400 & 5,298 & 5,216 \\
\hline 7. Head is over age 17 & 5,455 & 5,447 & 5,291 & 5,397 & 5,295 & 5,213 \\
\hline \multicolumn{7}{|c|}{ Line 7 gives a total of 32,098 households that are used in the first-stage "housing sample." } \\
\hline $\begin{array}{l}\text { 8. Number of related children, } \\
\text { ages } 6 \text { to } 17\end{array}$ & 6,760 & 6,773 & 6,563 & 6,659 & 6,506 & 6,674 \\
\hline
\end{tabular}

Note: When both a husband and wife were present, we assigned the husband as the "household head." 
APPENDIX TABLE 3

Definition of Held Back, and Probability of Being Classified as Held Back by Age

\begin{tabular}{|c|c|c|c|c|c|c|c|c|c|c|c|c|}
\hline Age & & 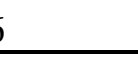 & & 7 & & $8-11$ & & \multicolumn{2}{|c|}{$12-15$} & 16 & & \\
\hline Held back if: & & School & & Kindergarten & & $<$ grades $1-4$ & & $<$ grade & & $<$ grade 9 & & de 10 \\
\hline Age & 6 & 7 & 8 & 9 & 10 & 11 & 12 & 13 & 14 & 15 & 16 & 17 \\
\hline$\%$ held back & 6.95 & 1.70 & 4.49 & 2.05 & 0.32 & 0.27 & 6.08 & 2.22 & 1.01 & 0.47 & 6.69 & 8.47 \\
\hline
\end{tabular}


APPENDIX TABLE 4

Robustness Checks (from Census Using Two-Sample IV, Renters and Homeowners)

Family Is

Overcrowded
Child Was

Held Back

A. Other covariates include:

child's age and sex (in column 3),

head's age, sex, and race.

Participation in public housing

$-.1794 \quad(.0656)$

$-.1273 \quad(.0457)$

$-.1876(.0711)$

B. Other covariates include:

covariates in Table 7, plus

household income and its square.

Participation in public housing

$-.1028 \quad(.0646)$

$-.1330$

(.0480)

$-.1727(.0723)$

C. Head has high school or less, includes covariates in Table 7 , 184,523 in "Housing Sample" and 232,708 in "Child Sample."

Participation in public housing

D. Head has at least some college, includes covariates in Table 7 , in 257,924 "Housing Sample" and 329,510 in "Child Sample."

Participation in public housing $-.0354 \quad(.0790)$ $-.1029 \quad(.0723)$ $-.1675(.0919)$

Notes: Standard errors in parentheses. Standard errors in column 3 are corrected for multiple children in same household. 


\section{References}

Aaron, Henry. 1972. Shelter and Subsidies: Who Benefits from Federal Housing Policies? Washington DC: Brookings Institution.

Angrist, Joshua, and William Evans. 1996. "Children and Their Parent's Labor Supply: Evidence from Exogenous Variation in Family Size.” NBER Working Paper No. 5778. Forthcoming, American Economic Review.

Angrist, Joshua, and Alan Krueger. 1992. "The Effect of Age at School Entry on Educational Attainment: An Application of Instrumental Variables with Moments from Two Samples." Journal of the American Statistical Association 87: 328-336.

Angrist, Joshua, and Alan Krueger. 1995. "Split-Sample Instrumental Variables Estimates of the Return to Schooling." Journal of Business and Economic Statistics 13: 225-235.

Apgar, William. 1990. “Which Housing Policy Is Best?” Housing Policy Debate 1: 1-32.

Atlas, John, and Peter Dreier. 1993. "From 'Projects' to Communities: Redeeming Public Housing." Journal of Housing 50: 21-34.

Barrington, Byron, and Bryan Hendricks. 1989. "Differentiating Characteristics of High School Graduates, Dropouts, and Nongraduates.” Journal of Educational Research 82: 309-319.

Butcher, Kristin F. and Anne Case. 1994. "The Effect of Sibling Sex Composition on Women's Education and Earnings." Quarterly Journal of Economics 109: 531-563.

Cairns, Robert B., Beverley D. Cairns, and Holly J. Neckerman. 1989. "Early School Dropout: Configurations and Determinants." Child Development 60: 1437-1452.

Case, Anne, and Lawrence Katz. 1991. "The Company You Keep: The Effects of Families and Neighborhoods on Disadvantaged Youth.” NBER Working Paper No. 3705.

Coggon, David, D.J. Barker, Hazel Inskip, and G. Wield. 1993. "Housing in Early Life and Later Mortality." Journal of Epidemiology and Community Health 47: 345-348.

Condon, Mark. 1991. Public Housing, Crime, and the Labor Market: A Study of Black Youths in Chicago. Harvard University Senior Thesis, Cambridge, MA.

Crews, Amy. 1996. "Do Housing Programs for Low-Income Households Improve Their Housing?" Mimeo, Maxwell School of Citizenship and Public Affairs, Syracuse University, Center for Policy Research.

Ensminger, Margaret, and Anita Slusarcick. 1992. "Paths to High School Graduation or Dropout: A Longitudinal Study of a First-Grade Cohort." Sociology of Education 65: 95-113. 
Fischer, Claude, and Mark Baldassare. 1975. "Crowding Studies and Urban Life: A Critical Review." Journal of the American Institute of Planners 41: 406-418.

Galpin, O.P., C.J. Whitaker, and A. J. Dubiel. 1992. "Helicobacter pylori Infection and Overcrowding in Childhood." Lancet: 339(8793): 619.

Grissom, James, and Lorrie Shepard. 1989. "Repeating and Dropping out of School." In Flunking Grades: Research and Policies on Retention, eds Lorrie Shepard and Mary Lee Smith, New York: Falmer Press.

Jencks, Christopher, and Susan Mayer. 1990. "The Social Consequences of Growing up in a Poor Neighborhood." In Inner-City Poverty in the United States, eds Laurence Lynn and Michael McGeary, Washington, DC: National Academy Press.

Kaestner, Robert. 1997. "Are Brothers Really Better? Sibling Sex Composition and Educational Achievement Revisited." The Journal of Human Resources 32: 250-284.

Katz, Lawrence, Jeffrey Kling, and Jeffrey Leibman. 1997. “The Impact of 'Moving to Opportunity' and Out of Public Housing in Boston." Mimeo, Harvard University.

Kotlowitz, Alex. 1991. There Are No Children Here: The Story of Two Boys Growing Up in the Other America. New York: Doubleday.

Kuo, Hsiang-Hui Daphne, and Robert Hauser. 1996. "Gender, Family Configuration, and the Effect of Family Background on Educational Attainment.” Social Biology 43: 98-131.

Mann, S. L., M. E. Wadsworth, and J. R. Colley. 1992. "Accumulation of Factors Influencing Respiratory Illness in Members of a National Birth Cohort and Their Offspring." Journal of Epidemiology and Community Health 46: 286-292.

Murray, Michael P. 1983. "Subsidized and Unsubsidized Housing Starts: 1961-1977." Review of Economics and Statistics 65: 590-597.

Olsen, Edgar. 1983. "Implications for Housing Policy.” In The Great Housing Experiment, eds Joseph Friedman and Daniel Weinberg, Beverly Hills: Sage Publications.

Olsen, Edgar, and David Barton. 1983. "The Benefits and Costs of Public Housing in New York City." Journal of Public Economics 20: 299-332.

Rosenbaum, James. 1992. "Black Pioneers: Do Their Moves to the Suburbs Increase Economic Opportunity for Mothers and Children?" Housing Policy Debate 2: 1179-1213.

Rubin, David, Candace Erickson, Mutya San Agustin, Sean Cleary, Janet Allen, and Patricia Cohen. 1996. "Cognitive and Academic Functioning of Homeless Children Compared with Housed Children." Pediatrics 97: 289-294. 
Sontag, Deborah. 1996. "For New York City's Poorest, Life 'Trapped in a Cage."” The New York Times, October 6.

U.S. Department of Housing and Urban Development. 1993. Handbook No: 7420.3: Section 8 Housing Assistance Payments Program Existing Housing and Moderate Rehabilitation Processing, Washington, DC. February 17.

U.S. Department of Housing and Urban Development. 1996. The Transformation of America's Public Housing, www.hud.gov/pih/publications/transform/pihcont.html\#content.

U.S. Department of Housing and Urban Development. 1997. A Picture of Subsidized Housing, Washington, DC.

U.S. House of Representatives, Committee on Ways and Means. 1996. Green Book. Background Material and Data on Programs within the Jurisdiction of the Committee on Ways and Means, http://www.access.gpo.gov/congress/wm001.html.

U.S. General Accounting Office. 1994. Elementary School Children: Many Change Schools Frequently, Harming Their Education. Washington, DC: Government Printing Office, General Accounting Office/HEHS-94-45.

U.S. General Accounting Office. 1995. Public Housing: Converting to Housing Certificates Raises Major Questions About Cost. Washington, DC: Government Printing Office, General Accounting Office/RCED-95-195.

Wilson, William Julius. 1987. The Truly Disadvantaged: The Inner City, the Underclass, and Public Policy. Chicago: University of Chicago Press. 